\title{
Legal Translation Instruction at Discourse Level and the Problem of Equivalence
}

\author{
Basim Yahya Jasim Algburi \\ Department of English, College of Arts, University of Mosul, Iraq
}

\begin{abstract}
Legal translation is often claimed to be one of the most difficult types of technical translation. The difficulty may partly be due to the characteristic features of legal discourse which is typically archaic, obscure, complex, and culturally-bound, different linguistic systems, and the type of equivalence the legal translator seeks to achieve; and partly be due to the item-centered approach commonly used in teaching legal translation which emphasizes word-for-word equivalence. The present paper introduces a discourse-oriented approach as an alternative to the currently-used method of teaching legal translation in Iraqi universities. The major argument is that teaching legal translation at discourse level helps the students of translation to recognize the lexical, grammatical, pragmatic, and stylistic dimensions of the legal text which are essential for providing appropriate legal equivalence.
\end{abstract}

Keywords: legal translation, legal equivalence, translation instruction, discourse-oriented approach, characteristics of legal discourse

DOI: $10.7176 / \mathrm{JEP} / 11-17-03$

Publication date:June 30th 2020

\section{Introduction}

Legal translation is a special type of technical translation which involves the transcoding of a legal text in one language into another. This type of translation has historically played a significant role in the contact between legal systems, norms, rules of conduct and behavior of different cultures and nations. The translation of law is often claimed to be the most difficult type of technical translation. This difficulty may be due to : the different legal systems, the complexity of legal terminology, and the type of equivalence the translation of legal documents aims to achieve.

The present paper discusses the nature of legal discourse and its consequences on legal translation; the sources of difficulties which students of translation often encounter when translating legal texts especially English legal texts into Arabic, and the types of equivalence the legal translator seeks to achieve . Finally, it suggests a discourse-oriented approach to teaching legal translation taking into consideration the difficulties encountered by the translation students in achieving optimal legal equivalence at lexical, grammatical, and textual levels. The research is guided by the following research questions:

1. What are the sources of difficulty in translating English legal texts into Arabic?

2. How can the discourse-based approach suggested be helpful in overcoming the difficulties that face legal translation students in providing legal equivalence at various levels of linguistic analysis?

\section{Legal Discourse: Nature and Types}

Legal Translation is a type of technical translation which involves rendering of a legal text in one language into another. Bold claims are often made about the complexity of legal translation and the distinctive nature of legal discourse. Grazone (2000:3) points out that legal translators are subject to the heaviest semiotic contrasts at all levels: the language of the law is typically formulaic, obscure and archaic; the legal discourse is culturally mediated; and the legal texts have special pragmatic status. Koutsivitis (1988) as cited by Harvey (2002:179) ascribes the special status of legal translation to " the prescriptive nature of legal discourse, which gives rise to legal effect". Taking this point into consideration, Sarcevic (1997:11) singles out three types of legal texts: primarily prescriptive such as, codes, , treaties, contract and conventions ; primarily descriptive such as decisions, actions ,appeals , petitions ; purely descriptive such as, law textbooks, articles and the like. Bhatia (1987:227-229) draws a distinction between spoken and written legal discourse .Spoken legal discourse involves : the pedagogically oriented lectures and moots, the academic lectures, textbooks, cases, judgments and professional lawyer - client consultation, counsel -witness examination and jury instruction . Written legal discourse contains contract, agreements, insurance policies, which usually take frozen forms, and legislative rules and regulations which are basically formal. Cao (2010: 79) goes further in distinguishing four variants of written legal texts : legislative texts, for example, statutes, international treaties, etc. ; judicial texts produced in the judicial process; legal scholarly texts produced by academic lawyers or legal scholars; and private legal texts which include texts written by lawyer, for example contracts, leases, wills and litigation deeds, etc. These different text-types have their own peculiarities and have various communicative functions. Cao (ibid) identifies two communicative purposes: normative and informative .legal texts have a normative function when they 
establish legal facts or create rights and obligation. These are mostly prescriptive. legal texts like legal advice, correspondence between lawyers, and commentaries are said to have an informative function. These are mostly descriptive .These two functions are highly relevant in legal translation because they have much to do with what Beaupre' ( 1986) as cited in Garzone (2000:5) calls ' legal equivalence ' which accounts for the legal effects that a translated text will have in the target culture .

Legal translation as the rendering of a legal text from one language to another can be classified in terms of: subject matter, status, functions, and purposes. According to subject matter, legal translation involves translating: domestic statutes, international treaties, private legal documents, legal scholar works and case law. In terms of status, the source text can be enforceable law, such as statutes; or non-enforceable law, such as legal scholarly works. As for function, the legal text in the source language may be primarily prescriptive, for example codes, regulations, contracts; purely descriptive, for example law textbooks and scholarly works; and hybrid texts which contain both functions: descriptive and prescriptive, such as judicial decisions, briefs, requests etc. In the light of purpose of the to-be-translated texts, first there is legal translation for normative purposes: producing of equally authentic legal text in bilingual or multilingual jurisdiction of domestic laws and international legal instruments, where the source text and the translated texts have equal legal force: no one is superior to another. Secondly, there is also legal translation for information purposes. This includes the translation of statutes, court decisions or scholarly works to provide information to the target readers for the benefit of foreign lawyers. Of course, the translated texts are not legally binding, only the original texts have force. Thirdly, legal translation can have general judicial purpose. Such translation is primarily used in court proceedings as part of documentary evidence, such as, contracts and agreements, records, expert reports among many others ( Cao, 2010:81-82).

It is apparent from the discussion above that legal texts are highly complex and multi-faced having different status, varied functions and multi subject matters. The translator of legal discourse should, therefore, take all these matters into consideration when translating a given legal text from one language to another.

\section{Sources of Difficulty in legal Discourse}

Translation of legal discourse has traditionally been recognized as posing a great challenge to novice translators and Arab translator are, of course, no exception. Various sources of difficulty have been identified in the literature. Garzone (2000) ascribes the difficulty of legal translation to : the characteristic features of the legal discourse, its culturally- mediated nature, its special pragmatic nature as well as the type of legal equivalence it aims to achieve. Altay (2002) argues that the source of difficulty lies in the difference in legal systems, the difference in language systems, the terminology specific to each legal system, the unusual structure of legal discourse, and the use of common terms with uncommon meanings. Sarcevic (1997) argues that the difficulty might be due to the system of reference, terminological incongruity and the natural vs. linguistic equivalence. Cao(2007) points to "the systematic differences in laws, linguistic differences and cultural differences " (p.23) as the major sources of legal translation difficulty. As far as English to Arabic legal translation is concerned, it seems to me that the major causes of difficulty in translating legal texts from English into Arabic or Arabic into English are : the different legal systems, the nature of the legal discourse and the finding of appropriate equivalence to create the same legal effect.

\subsection{Differences in legal systems}

To begin with, English legal system has been heavily influenced by the forces that shape the English nation in general. Tiersma (2008:8) argues that present -day legal English has been affected by "Anglo-Saxon mercenaries, Latin- speaking missionaries, Scandinavian raiders, and Norman invaders all of whom left their marks not only on England but also on its language ". By contrast, the sources of Arab laws in general and the Iraqi Laws in particular are multivariate. The Family Law is based on ' Alsharia'a Al-islamiya ', the civil code on French laws, The Criminal law basically on British criminal law , and public and private international law on French and British international laws. These different sources have undoubtedly had a bearing on the translation of certain legal concepts and principles that are found in one legal system and might be absent in another. In such cases finding various types of equivalence to create the same legal effect is not easy to achieve. For example, concepts like الوقف Al-Waqf ' الثفعة 'Al-shufa'a', التعزير 'Al-taa'zeer ' and-Idda' in Arabic legal system are roughly translated in to ' inalienable estate ', ' preemption ', ' chastisement ', and, periods, respectively, because they have no equivalents in the English legal system . By contrast, ' jury ' ' magistrate office', and 'martial law' are difficult to translate into Arabic because they have no equivalents in Arabic legal system.

\subsection{The Characteristic Features of English legal VS. Arabic legal Texts}

The second source of difficulty for the students of translation in binomials and multinomial, for example translating legal discourse in general and legal documents in particular is the complex nature of legal texts at lexical, syntactic, semantic, and stylistic levels.

At lexical level, legal English is characterized by : using technical terms such as ' real property ', forfeiture', 
felony ', archaic expression coming down from Latin or old English such as ' aforesaid ', ' hereinafter ', ' thereof', doublets or binomials, 'cease and desist, 'aid and abet,' goods and chattels', or multinomials such as ' throw down, drops or otherwise deposits'. By contrast, adjectives that refer to sentiments such as' happy' , 'disgusting' ,' marvelous' and intensifying adverbs like 'very', 'rather', 'extremely', are completely, absent . (Cf. Crystal and Davy,1969:206,208; Danet 1985: 279, 281; Gustaffon ,1984:125)

At the semantic level, legal discourse, also, contains a lot of collocations in which synonyms and near synonyms are coordinated in quite extensive list through the use of binomials and multi-nomials (crystal and Davy $1969: 208$; Bhatia $2006: 3$ ). The motivation is to cover every base and anticipate every contingency (Tiersma, $2008: 15$ ). For example

'He who Solicited for himself or as a third party, or accepted or received a promise or a gift to perform any duties of his function or claims ... (Saudi Arabia : Anti- bribery Law)

من طلب لنفسه او لغيره او قبل او تلقى وعدا او هدية للقيام باية اعمال تقع ضمن وظيفته او اختصاصه

Also , there are many words that have both an ordinary as well as a legal meaning. This is called by Tiersma (1999:111) 'legal homonyms' such as: 'minutes', 'instruments', ' file a complement ', ' defendant ', ' decree ', ' property ' and the like.

At the syntactic level, syntactic features of legal discourse are probably more distinctive than semantic ones. The major syntactic features identified in the literature on legal genre are: the extensive use of nominalization, the prominence of passive constructions, the omission of wh-forms plus some forms of the verb to be, the frequent use of conditionals, prepositional phrases and coordinated adverbials (Danet 1985: 281-283). Yet, the most obvious syntactic feature of legal language is the use of extremely long sentences ( Tiersma , 2007: 4) . Length and complexity go hand in hands. The legal sentence is highly complex. It contains a lot of words and a number of embedded sentences. Hiltunen (1984:108) found that the average sentence in the British Road Traffic Act of 1972 had 79 words.

Embedding is a notable syntactic feature that characterizes legal provisions (Crystal and Davy, 1969 ; Danet,1985). It is a syntactic process whereby a clause or a sentence is nested or embedded into the structure of a higher constituent. For Halliday (1985: 219-220), embedding is a mechanism in which a clause or phrase comes to function as a constituent of a clause so that the embedded clause functions in the structure of a group, and the group functions in the structure of the clause.

Quirk et al. (1985) points out that embedded clauses or sentences are introduced by complementizers which can be a noun, verb, adjective or preposition to indicate that the immediate constituent following it is a subordinate or embedded clause or sentence. The embedded clause functions as an expansion essentially defining, delimiting or specifying what is mentioned before. This structural phenomenon is found in both English and Arabic legal texts. Consider the following examples:

1. No person may become a member of a senate or chamber of deputies who is not a_national of Iraq...or who has lost his civil rights. (The Constitutional Law of Iraq of 1928)

$$
\text { 1. لا يكون عضواً في مجلس الأعيان أو مجلس النواب من لم يكن عر اقياً...أو من فقد حقوقه المدنية. }
$$

2. A sign shall not be registered as a trade mark if it consists exclusively of the shape which results from the nature of the goods themselves. ( Iraqi Trademark Law of 1937)

2. لا تسجل العلامة علامة تجارية إذا تألفت بالكامل من الثكل الذي ينشأ من طبيعة البضاعة نفسها.

In terms of form, embedded sentences are realized as finite, non-finite or verbless clauses (Quirk et al., 1985). In terms of syntactic functions embedded clauses function as noun clause, adjective clause or relative clause with adverbial gaps (Biber et al., 1999: 624).

I learnt that he has been convicted of larceny. (Embedded noun clause).

He will be treated on the offences which he committed when he was a president. (Adjective clause).

$$
\text { علمت انه أدين بتهمة السرقة. }
$$

The time that the crime had been committed has not yet been determined.

$$
\text { لم يحدد الوقت الذي ارتكبت فيه الجريمة بعد. }
$$

In terms of position, Hilton (1984) as cited by van Dijk (1985: 283) identifies four places: left branching, right branching, left rested and right nested. It is left-branching when it occupies the position of the subject; right-branching when it is located on the right side of the predicate; left-and right-nested are inserted within the structure of an endocentric phrase

The syntactic structure of legal English probably constitutes a major problem for the Arab students of translation because Arabic word order differs from that of English. Arabic is of VSO type whereas English is of SVO type. The translator should, therefore, have to follow the word order of the target text in order to achieve syntactic equivalence (see below). Furthermore, English sentence is by definition verbal: it must contain a subject and a predicate (a verb); Arabic sentence can be verbal (containing a verb) or nominal (containing two or more nouns without a verb). e.g. Misdemeanour is an offence punishable by fine or imprisonment 
الجنحة جريمة يعاقب عليها بالحبس أو الغر امة

The copula is omitted in Arabic version to create syntactic equivalence.

As is the case with English, Arabic legal sentence is highly complex: it contains a lot embedded clauses (sentences) called جمل فرعية (minor sentences).

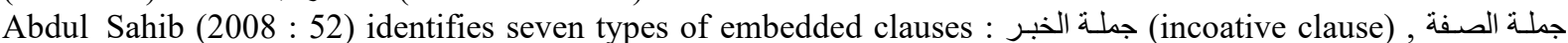
(adjective clause), جملة الحال (adverb of manner clause), جملة الصلة (relative clause), جملة الإضـافة (genitive clause) جملة المفعول , جملة الثرط (predicate clause), anditional clause), each has specific structure and relation to the main clause.

At supra-sentential level, Danet ( 1985 :285) speculates that the true distinctiveness in legal discourse may lie at discourse level .Crystal and Davy (1969) and Kurzon (1983) found that cohesive devices especially anaphoric reference - are particularly low, substitution may be generally rare, and ellipsis may also be lacking . By contrast, lexical cohesion in the sense pointed out by Halliday and Hassan (1976) is abundant of synonyms, near-synonyms, and super-ordinates are extensively used to refer to the items previously mentioned. The aim is to avoid ambiguity, and to make the words say what they exactly mean . Concerning coherence Kurzon (1983) found that legal texts have identifiable thematic structure known only to experts. Danet (1985) also adds that legal texts are characterized by extreme proposition density and lack of redundancy. This is usually expressed by the unusual length and complexity of legal sentences.

Stylistically, legal language tends to be impersonal. This impersonal style is realized through the extensive use of passivization and nomial constructions .In litigation and courtroom , Judges tend to speak in the third person . Tiersma (2002:178) states that authorless is a stylistic feature of legal language, especially in statutes . However, Harvey (2002:178) notes that there are cases of legal documents in which the first person singular is prominent, for example, wills, contracts, judicial opinions of the House of Lord . Precision is the second stylistic feature of legal texts . This precision is expressed through synonymy or near - synonymy especially when the superordinate or general term can lead to debate or misinterpretation (Tiersma $2007: 21$ ), through definition of legal terms or through careful repetition of words to delimit the scope of the action that might have legal consequences . Bhatia (2006:3) points out that in addition to precision and unambiguity, legal genre is notorious for being all - inclusive . This is often achieved through binomials and multi-nomials . For example:

" For any person corruptly to solicit, receive or agree to receive, for himself or any other person, any gift, loan or advantage as an inducement to, or reward for or otherwise on account of any member, officer or servant of a public body ....." ( Hooper 1968:161)

This very complex syntax with high incidence of collocation, binomials and multi-nomials and embedded clauses, a high level of hypo-taxis and frequent resort to left branching subordinate clauses ( Garzone ,2000:3) make the information load borne by each sentence extremely heavy .

\subsection{Finding Appropriate Equivalence}

The Third major problem that faces novice legal translator is the provision of appropriate equivalents to create, as far as possible, the same legal effect. The notion of legal equivalence, in fact, constitutes a real challenge to the translator of legal discourse and to achieve it in actual practice has been a subject of heated discussion . To begin with, a discussion of the major types of equivalence will be made and the relevance of these types to legal discourse will then be pointed out .

Generally speaking $\mathbf{X}$ is said to be an equivalent of $\mathbf{Y}$ if both are virtually the same .In translation, source language (SL) and target language (TL) texts or items are " translation equivalents when they are interchangeable in a given situation " ( Catford 1965 :94). The case of absolute equivalence, however, at various levels of the text in translation can hardly be achieved " One - to-one correspondence exists only in cases where the technical terms of a given discipline have been assigned the same definition in two or more languages " ( ReiB( 1995) as cited by Sarcevic (1997: 234) Thus, equivalence has always been a central concept in translation theory and various typologies focusing on various aspects of equivalence have been introduced. Baker (1995,2011) focuses on the rank - word, sentence, and text level -at which equivalence is said to obtain. She also makes a distinction between grammatical equivalence, pragmatic equivalence and textual equivalence distinguishing between the equivalence achieved through cohesion and the equivalence achieved through thematic and information structure. Koller ( 1989) as cited in Kenny (2009:97) concentrates on the type of meaning ( denotative, connotative, pragmatic, etc. ) that is prioritized in particular instances of translation .Thus referential or denotative equivalence is achieved when the source text (ST) and the target text (TT) words refer to the same thing in the real world. Connotative equivalence occurs when the ST and TT words trigger the same or similar association in the minds of native speakers of the two languages. Pragmatic equivalence is achieved when the ST and TT have the same effect on their respective readers .Baker (2011) extends the concept of equivalence to cover similarity in the ST and TT in the linear arrangement of linguistic elements and the organization of the messages paying attention to the cohesive devices and information structure in both texts .These two features constitute what she calls textual equivalence ( Baker, 2011 :131-229). Newman (1994) 
as cited by Kenny (2009:99) points out that not all the variables in translation are relevant in all situations , and that the translator must decide which type of equivalence should be given priority, thus establishing a kind of functional equivalence. This last type of equivalence is particularly relevant to legal translation.

In addition to the typology of equivalence, already mentioned, in the domain of legal translation, the notion of legal equivalence ' prevails. Schroth (1986) as cited by Cornelius (2011: 130 -131) suggests that " the legal translator must know how to achieve the same legal effect in the target language "Sarcevic ( 1997:71) goes further in proposing equivalent legal effects as a criterion for measuring success in legal translation . Finding equivalents for culture - bound terms is not an easy task. It contradicts fidelity which is traditionally regarded as the major criterion for evaluation of legal translation. Fidelity as formal correspondence between source and target text must therefore be redefined to justify substantial changes to the original text to respect the stylistic conventions of the target legal culture ( Sparer (1979) as cited by Harvey (2002:180) in order to achieve legal equivalent effect .Thus, the principle of legal equivalence adds the consideration of the legal effects that a translated text will have in the target culture to other criteria of equivalence . Garzone (2000:5-7) confirms that the concept of legal equivalence is not unconditionally suited to all situations and text types ,so that the translator may adopt different procedure to translate different legal texts in order to guarantee adequacy to the function the TT is expected to fulfill in the target context .

\section{A Discourse-oriented Approach to Legal Equivalence}

Equivalence in legal discourse should be viewed in a wider perspective. It encompasses lexical, syntactic and discourse equivalences. The present section accounts for these types of equivalence and how these types are viewed within the discourse oriented approach to teaching legal translation.

\subsection{Lexical equivalence}

To begin with, in typical legal translation classroom, translation students are most often instructed to consult a legal bilingual dictionary to look up the new legal terms. This approach to teaching legal terms is misleading because the lexical equivalent highly depends on the relation of the lexical item to other items in the text and the restrictions each language imposes upon the choice of words and the relationship between them.

To bridge this gap, teaching legal terms to the students of legal translation can be discourse-oriented in that students of translation can account for the discourse dimension of the items in both the source and the target texts and how the legal item is related to other items surrounding it (co-text) and the situation in which the discourse is produced in addition to the communicative function a legal text may perform in the SL and/or TL context of use.

The discourse-oriented approach suggested partly adopts Halliday and Hassan's (1976) notion of "lexical cohesion". Lexical cohesion refers to the semantic relationship between lexical items especially content words. It is "the cohesive effect achieved by the selection of vocabulary" (Halliday and Hassan, 1976: 275). Lexical cohesion is mainly achieved through reiteration and collocation.

Reiteration includes not only repetition of the lexical items but also the occurrence of related items. Thus, reiteration encompasses repetition, synonymy, antonymy, hyponymy and meronymy.

Repetition refers to the words that are repeated in a text. Consider the following examples:

a- Private property is protected and the owner shall have the right to benefit, exploit and dispose of private property within the limits of the law.(Article 32 (A) of Iraqi Constitution of 2005).

In this example 'private' property' has been repeated. Yet this repetition is replaced by the repetition of the pronoun $\mathrm{sin}$ Arabic

$$
\text { الملكية الخاصة مصونة ويحق للمالك الانتفاع بها و استغلالها و التصرف بها. }
$$

b- A nominee to the presidency must be an Iraqi by birth, born to Iraqi parents. (ibid)

$$
\text { يشترط في المرشح لرئاسة الجمهورية أن يكون عر اقياً بالو لادة ومن أبوين عر اقيين }
$$

Synonymy: refers to words which are similar in meaning. Hurford and Heasley (1983: 103) point out that synonymy is a relation between predicates and not between words (word forms) where each distinct sense of a word is a predicate. For example, 'convicted/charged', 'offence/crime', 'proof/evidence', 'excitable/pugnacious'. Antonymy describes opposite or contrastive meaning. They can be gradable such as 'hot/warm, timid/cold, nongradable such as 'rights/obligations', relational such as 'offer a bribe/accept a bribe'. Hyponymy refers to classes of lexical items where the relationship between predicates is one of general-specific (Paltridge, 2006: 135). Hurford and Heasley (1983: 105) view it as a sense relation between predicates such that the meaning of one predicate is included in the meaning of the other. For example, 'manslaughter' and 'murder' are two hyponyms to the superordinate 'homicide'. The difference between 'murder' and manslaughter' lies in the availability of the malice in the first rather than the second. Meronymy is a technical term for part-whole relationships. The parts are defined in terms of specific functions. The head is the part of the body that carries the most important sense organs: eyes, ears, nose and tongue (Löbner, 2002: 96-97). In legal genre, consider the following example:

In civil proceedings, to secure the appearance of the alleged offender, the prosecution "may issue a summons directed to that person requiring him to appear before the court to answer to the information; or he may 
issue a warrant to arrest that person and bring him before the court".

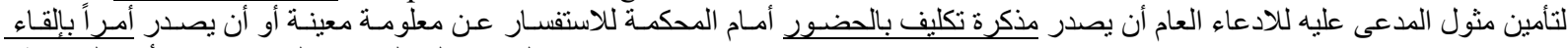

القبض على المدعى عليه و إحضاره أمام المعان المحكمة.

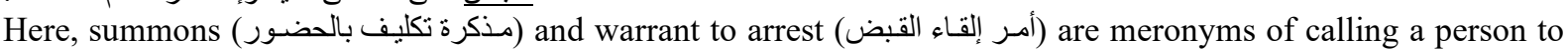
appear before the court having two functions and two implications.

The same applies to courts where the function of the court of appeals (محكمة الاستئناف) is completely different from that of the court of conciliation (محكمة الصلح) or of the court of inquiry (محكمة التحقيق)

Collocation is another instance of lexical cohesion. It was first introduced by Firth (1957) to refer to the tendency of a word to regularly co-occur with another in a given linguistic context. For example, in English 'rancid' tends to collocate with 'butter' and 'addled' with 'egg'. In Arabic 'شنّ' (wage) with 'طائفي' (war) and 'حرب' (sectarian) with 'إقتنال' ' war' or 'violence'. Baker (2011: 52) points out that this type of co-occurrence is "semantically arbitrary restrictions which do not follow from the propositional meaning of a word", and that the patterns of collocation are largely arbitrary and independent of meaning. Halliday (1966) as cited by Al-Halaby ( 2000: 13) divides the collocational expression into two elements: a node - an item that has a collocational behavior, and collocate-items that tend to co-occur with the node. For example, in commit a mistake, a crime, a wrongful act'. 'Commit' is the node and 'mistake', 'crime' and 'wrongful act' are collocates. The same applies to

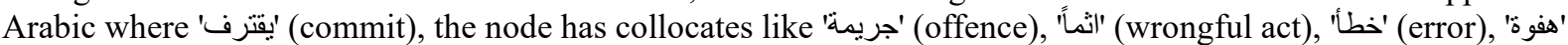
(mistake).

This type of lexical relationship has a number of properties the most important of which are: a) nonreciprocality: the word 'commit' suggests 'crime', 'mistake' and the like rather than positive epithets; b) Limited compositionality: the items of collocation limit each other's meaning to only one possible meaning; and c) limited substitutionality, for example, 'strong' and 'powerful' are synonymous, yet 'strong' rather than 'powerful' collocates with 'tea'; arbitrariness in that there is no sound reason why a given word collocates with another (Carter, 1988; Manning and Schutze, 1999; Lewis, 2002).

Syntactically, collocation has a wide range of patterns: verb + noun such as 'pay a visit / attention', noun + verb such as 'lions roar, earth revolves', verb + adverb/adjective such as work hard, 'smell sweet', noun + of + noun such as 'a bar of chocolate', 'a flock of birds' (see Grains et al., 1986 for more details). Collocation is a characteristic feature of most of human languages yet the patterns of collocation are by and large arbitrary and independent of meaning. This is why word for word translation cannot work well most of the time. The translator must account for the restriction imposed on the choice of words in the TL and those imposed on the SL. Baker $(2011,53)$ rightly notes that the verb 'deliver' in English can be translated differently in Arabic according to the types of collocate it attaches to. For example 'deliver' in 'deliver a letter' is translated as يسلم, in deliver a speech 'يلقي' , in deliver a blow 'يصلقى' , in deliver a verdict 'ينقي' and in deliver a baby 'ينجر'.

When teaching legal translation, students' attention should be drawn to the fact that word to word translation can be misleading if collocation and its restrictions imposed upon the choice of words in the SL and TL texts are not taken into consideration. Note how the verbs "pass" has different renderings in Arabic according to the collocates that attach the node or the recurrent part. For example: pass in 'pass a judgment' is translated as

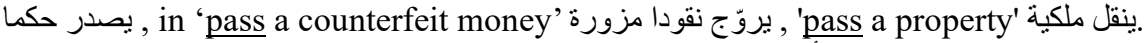

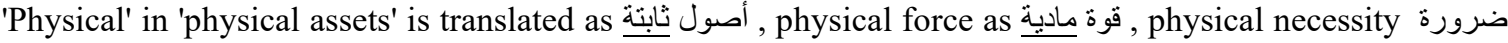
ملزمة and physical incapacity عجز بدني.

These examples clearly show that different words have different collocates in different languages, a characteristic feature which cannot be accounted for by in an item- centered approach to teaching legal translation which focuses on lexical items as separate items.

\subsection{Grammatical equivalence}

The second type of equivalence which the discourse-oriented approach attempts to draw the students of translation attention to is the grammatical equivalence. To begin with, grammar is basically concerned with how words are structured and arranged in a given language. Each language has its own set of rules to form words and to sequence them. for example English count nouns have two forms: singular and plural, man/men. By contrast Arabic count nouns have three forms: singular, dual, and plural, for example رجال/رجلان/رجل.

Also, each language has its own set of arrangements of the functional elements which is the concern of word order. Word order is the major concern of syntactic theory. It refers to the order in which functional elements such as subject, predicate, object and adverbial occur in the structure of the sentence of a given language. The ordering of these functional elements "plays a major role in maintaining a coherent point of view and in orienting messages at text level" (Baker, 2011: 120). Languages differ in the way they order the language elements and the degree of stability of the order of these elements. English, for example, is an SVO language and the order of its linguistic elements is relatively fixed. By contrast, Arabic is a VSO language and the functional elements in the sentence are relatively free depending heavily on case inflection.

The order and sequence of words in a given language have a bearing on the content and degree of 
importance the speaker or writer gives to the items of information conveyed and the textual structure of the message imparted. The elements of the grammatical structure and processes such as word order, passive constructions, and embedding will be accounted for in both English and Arabic at discourse level seeking for grammatical equivalence in the translation of legal discourse.

Voice is another grammatical concept which defines the relationship between a verb and its subject. For Quirk et al. (1972: 801), voice is "a grammatical category which makes it possible to view the action of a sentence in two ways, without change in the facts reported". Voice can either be active or passive. In active clauses, the subject is the agent responsible for performing the action instigated by the verb. In passive clauses, the subject is the affected entity. For example:

a. In most jurisdictions, the defense attorneys or prosecutors issue their own subpoenas to compel the appearance of a witness.

b. In most jurisdictions, subpoenas to compel the appearance of a witness are issued by the defense attorney or prosecutors.

In English passive constructions, the agent may or may not be specified. By contrast, passive constructions in Arabic never specify the agent. The translation of passive construction in which the agent is specified constitutes a difficulty to Arab novice translators. This is because the passive constructions which contain the agents preceded by 'by' are translated in Arabic as active constructions especially when the specified agent is animate. Thus, in Arabic, passive constructions can be translated in two ways: as passive constructions when the agent is not specified in the same sentence or text; and as active constructions when the agent is specified. Consider the following examples:

1. Ministers are forbidden to buy or lease any of the movable or immovable property of the state. (Article 38 of the CLI).

$$
\text { يحرّم على الوزر اء شر اء أو إيجار أي من الأموال المنقولة أو غير المنقولة للاولة. }
$$

2. Decisions shall be taken by the a majority of votes of the members present, unless otherwise provided by this law. (Article 53 of the CLI).

$$
\text { تتخذ القرار ات بأغلبية أصوات الأعضاء الحاضرين مالم ينص هذا القانون على خلاف ذلك. }
$$

\subsection{Discourse equivalence}

Word order can be studied at sentence level and at supra-sentential or discourse level. At discourse level word order is viewed in terms of its effect on the information structure of the message the speaker or writer wants to convey. The information structure refers to the sentence as a message including two main parts: given or old information which is known to the receiver and can be recovered anaphorically or situationally from the context; and new information which is unknown to the receiver and unrecoverable from the context or preceding discourse (Mathesius, 1939: 234; Halliday, 1967: 211). Various dichotomies have been proposed to deal with the information structure Mathesius (1939) suggests 'theme' to refer to the older or given information, while 'rheme' to the new information; Hockett (1958) uses the terms 'topic' versus 'comment'; Chomsky (1971) recommends the terms 'presupposition' versus 'focus' to refer to the same notions.

The view of given / new information was further developed by Firbus (1964) who coined the term 'communicative dynamics' to refer to the contribution of sentence elements to the development of the communication. The linear arrangement has, therefore, a role to play in processing information and organizing message at text level allowing us to exploit word order occasionally in order to generate special effects (Baker, 2011: 132).

The discourse-oriented approach views a sentence not only as a grammatical unit having functional elements : subject, predicate, complement and adverbial but also as a semantic unit consisting of two segments: 'theme' and 'rheme'. The theme acts as a point of orientation connecting what is to be mentioned to a previous stretch of discourse and a point of departure contributing to the development of later stretches. The 'rheme' is what is mentioned about the 'rheme'. It is the very information that the speaker or writer wants to convey (Ibid: 133).

Generally speaking, the structuring of information in Arabic is context- determined. Context- depended elements represent old information or 'rheme' while context independent elements represent new information or ' rheme'. By contrast, information structure in English depends largely on word -order in the structuring of information. Also, Arabic has a relatively free word-order so that the speaker or writer of Arabic has more freedom to move elements from their normal position to achieve stylistic effects (Habeeb, 2006 ). English wordorder, on the other hand is said to be rigid and un-flexible (Quik et al 1985). Speakers or writers of English use existential constructions, thematization, cleftization, to rearrange sentence element to produce stylistic effects.

Existential 'there' followed by a form of 'be' is used to introduce new information. In Arabic is realized by deferring the innunciative and fronting the inchoative as in the example below:

There is another eye-witness at the door

$$
\text { ثمة شاهد عيان اخر عند البابمند الباب شاهد عيان اخر }
$$


In thematization, a sentence element is isolated as topic and shifted to the initial position as in the example below:

In the way he pronounced the plosives she was able to recognize him.

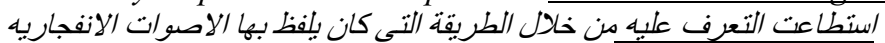

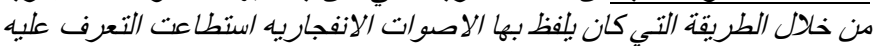

Cleftization involves cleaving the sentence into two clauses each with its own information structure. The first clause consists of 'it' and a form of 'be', and the second with a relative pronoun such as 'that' or 'who' ( Crystal,1990) as in

\section{It was her cousin who tried to bribe the traffic policeman}

الذي حاول ان بيرشو شرطي المرور كان ابن عميا

Thus both English and Arabic use end-weight principle to introduce the new information, but while Arabic uses word -order which is relatively flexible, English depend on syntactic processes such as thematization, cleftization, existential constructions, etc.

A notable difference in information structure between English and Arabic legal texts especially in civil proceedings and penal codes is that legal provisions in Arabic start with the penalty rather than criminal act or behavior; while legal provisions in these codes start with the criminal act or behavior rather than penalty. Consider the following example:

يعاقب بالحبس مدة لاتزيد على سنتين وبغر امه لا تزيد على مائتي دينار او باحدى هاتين العقوبتين كل من استتعل او انتفع بغير حق بمحرر صحيح صادر للغير

Any person who unlawfully makes use of or benefits from a genuine document issued for the use or benefit of another is punishable by a period of detention not exceeding 2 years plus a fine not exceeding 200 dinars or by one of these penalties (article 299 of Iraqi Penal Code of 1969)

Thus, when translating legal provisions, this discoursal or stylistic features should be accounted for if appropriate legal equivalence at discourse level is sought

\section{The Discourse-oriented Approach to Teaching Legal Translation}

Legal translation has been in great demand in Iraq and elsewhere due to the increasing contact and exchange between people and legal systems and the increasing needs for legal translation for various purposes. Legal translation instruction, however, is little researched and there is no agreement on how it should be taught and the types of competence the students of translation should develop.

This section provides insights into teaching English-Arabic legal translation. It discusses the types of competence required to develop in the students of legal translation. It focuses on the various aspects of equivalence which the students of legal translation need to account for. It ends up with suggesting a discourse based approach as an alternative to the item- centered approach to teaching legal translation.

As is the case with teaching other types of translation, in legal translation instruction in Iraq, as may be elsewhere, the teaching objectives are restricted to developing linguistic competence and acquainting students with legal terms and concept in the SL and TL texts. Apart from legal terminology, little attention is paid to the characteristic features of legal discourse and the competences required to develop in the students of legal translation. Coa (2010:115) maintains that in training legal translators four major areas are considered essential: general knowledge of legal translation theories and principles, legal- specific translation skills, general knowledge of the legal systems and specific areas of law, translation practice in different areas of law, professional ethics and legal obligations of translators, and technological tools for translation.

I do agree with Cao concerning the competencies needed by the legal translator but it seems to me that the student of translation essentially needs knowledge of legal discourse in the source and target language .

In order to capture the aspects of legal language and to provide solutions to the difficulties which translation students face in rendering legal equivalence, a discourse-oriented approach is suggested. Unlike the itemcentered approach whose ultimate aim is to provide word-for-word equivalence, the discourse-oriented approach to teaching legal translation views equivalence in a wider perspective. It is relational in that it shifts attention from lexical items in isolation to the relationship which the lexical item enters with other items to form a text or a piece of discourse which has a specific communicative function to perform. More specifically, this approach suggests textual analysis and emphasizes lexical relations such as synonymy, antonymy, hyponymy, meronymy, etc., on vertical axis and collocation, binomials and multi-nomials, on horizontal axis. Grammatical relations and processes such as word order, passivization, embedding, etc., and how these relations are utilized to make a given text or discourse cohesive at the level of form and coherent at the level of meaning should also be considered. It also accounts for how the information is introduced and sequenced to achieve what Firbas (1972) calls 'communicative dynamics'.

In opposition to the item-centered approach to teaching legal translation, the discourse-oriented approach focuses on two types of relations: lexical and grammatical and their realizations in the SL and TL and their contribution in achieving the same legal effect. More technically, teaching legal translation should involve 
drawing the translation students' attention to the SL aspects of lexical cohesion such as reiteration, collocation and other lexical relations and aspects of grammatical cohesion such as ellipsis, expansion, embedding, word order, voice, as well as the information structure and the effect of these aspects on the sequence and focus of information and the restriction imposed upon the selection of words to achieve coherence and to produce the same legal effect in both the SL and TL texts as far as possible

To implement this approach in a legal translation class, the following steps are suggested:

1. Ask students to read the source text closely, looking up the new words in a legal or bilingual dictionary.

2. Draw the students' attention to the relationship that may exist between some lexical items at sentence or above the sentence level and how they are interrelated to achieve lexical cohesion at the level of form and coherence at the level of meaning.

3. Analysis of the syntactic structure of the SL identifying the main clauses, the subordinate clauses (their structures, functions, types), the embedded clauses and their functions in specifying the referent should be made especially when the sentence is long or when the sentence contains embedded constructions. The aim is to help students know which items are related to which. Passive constructions should be highlighted and whether the agent is specified; whether certain elements have been pre-posed or post-posed to achieve a specific effect etc.

4. Special attention should be paid to embedded clauses. Embedded constructions constitute a real problem to our students of legal translation especially when the sentence contains two or more embedded clauses. The novice student of translation faces difficulty in identifying the main clause and the subordinate clauses attached to refers to which noun, adjective or predicate. Embedding can best be presented by using Chinese boxes or bracketing to show students the relevance of each embedded clause to the main or superordinate clause.

5. Students' attention should also be drawn to the distribution of information in the source text, reminding students that the distribution and sequence of information may be changed to produce optimal legal equivalence at lexical, grammatical and discourse level and achieve the same legal effect in the target text.

\section{Conclusion}

Legal translation is a multi-faceted process. Owing to the fact that legal sentence are characteristically long and complex, analyzing the source text lexically, structurally and probably functionally seems to be a must before any rendering can be made. It also assumes that the legal translator should have background knowledge in the legal systems of the source and target languages, the characteristic features of legal discourse, and the type of equivalence required to produce the same legal effect.

Legal translation instruction at discourse level suggested in the present study claims to capture all types of equivalence ( lexical, grammatical, and stylistic) needed to provide legal equivalence. This approach instructs the teacher of legal translation to analyze the source text focusing on inter-textuality and intentionality as well as functionality when seeking equivalence at sentential and supra-sentential level.

\section{References}

Abdul-Sahib, M. (2008) The Embedded Sentences in Arabic between Sibuweih Analysis and Chomsky's Transformational Generative Grammar. Ghareeb Press, Cairo. ( In Arabic).

Al-Halabi, S.(2000). 'Collocational Expressions in English-Arabic Translation'. Unpublished M.A. Thesis, University of Mosul.

Altay, A. (2002) 'Difficulties Encountered in the Translation of legal Texts: The Case of Turkey' . Translation Journal, 6, (4), 1-12.

Baker, M (2011) In Other Words: A Course book on Translation. Routledge: London.

Bhatia, V.K. 1987, 'Language of the Law'. Language Teaching, 20, (3), 227-234.

Bhatia, V.K. (2006) 'Legal Genre'. In; Brown, K.(ed.) Encyclopedia of Language and Linguistics. $2^{\text {nd }}$ ed. Oxford: Elsevier. PP.1-7

Biber, D. Johnson, S. Leech G., Conrad S. \& Finegan, E. (1991). Grammar of Spoken and Written English. Longman, London.

Cao, D. (2007). Translating Law. Multilingual Matters LTD, Cevendou.

Cao. D. (2010). 'Legal Translation: Translating Legal Language' in: Coulthard, M. \& Johnson, A. (eds.).The Routledge Handbook of Forensic Linguistics. Routledge, London.

Carter, R. and MacCarthy, M. (1988) Vocabulary and Language Teaching. longman, London.

Catford, J. C. (1965) A Linguistic Theory of Translation. Oxford University Press, London

Chomsky, N. (1971) Problems of Knowledge and Freedom. Pantheon, New York.

Cornelius, E.(2011) 'The Curious Case of Legal Translation' Journal of Literary Criticism, Comparative Linguistics and Literary Studies. 32, (1), 121-144.

Crystal, D. (1990) Rediscovering Grammar with David Crystal. Longman. London

Crystal, D. \&. Davy, D. (1969) Investigating English Style. Longman. london

Danet, Brenda (1985). "Legal Discourse" In : Van Dijk, T. (ed.) Handbook of Discourse Analysis Vol.1, 
pp.273-291 Academic Press, London.

Doblin, H. (1981). "Irreversible Binomials and other Paired Formulas in German" Language. (14), (1), 78-88.

Firbas, J. (1972) 'On the Interplay of Prosodic and Non-prosodic Means of Functional Sentence Perspective' In: Fried, V. (ed.) The Prague School of Linguistics and Language Teaching. Oxford University Press, London.

Firth, J. R. (1957) Papers in Linguistics. Oxford University Press. London.

Gairns , R. and Redman, S. (1986). Working with Words; A Guide to Teaching and Learning Vocabulary. Cambridge University Press, Cambridge.

Garzone , G. (2000). 'Legal Translation and Function Approaches: A Contradiction in Terms'. Available at: Http//www. Tradulex.org/actes2000

Gustafsson, Maria. (1984) “The Syntactic Features of Binomial Expressions in Legal English”. Text ,4 ( 1-3), 123-141.

Habeeb, R. T. (2006) 'Information Structure in the Holy Qura'n'Unpublished Ph.D. Thesis, College of Arts, University of Mosul.

Halliday, M.A.K. (1985) Introduction to Functional Grammar. Edward Arnold, London.

Halliday ,M.A K. and Hassan, R. (1976). Cohesion in English. Longman, London

Halliday, M.K., Mclntosh, A. \& Strevens, P. (1964) The linguistic Sciences and language Teaching . Longman Group limited. London.

Harvey, M. (2002). 'What's so Special about legal Translation?' Meta. XLVII, (2), 177-185

Hiltunen, R. (1984). 'The Types and Structure of Clausal Embedding in legal English' Text..3,(1)107-122

Hockett, Ch. F. (1958) A Course in Modern Linguistics. The Macmillan, New York.

Hooper, C. A. (1928) The Constitutional Law Of Iraq. Mackenzie \& Mackenzie. Baghdad.

Hooper, C. A. (1968) Harris's Criminal Law. Sweet and Maxwell, London.

Hurford, J, R. \& Heasley, B. (1983) Semantics: a Course book. Cambridge University Press, Cambridge.

Hayawi, N (ed.) (2006). Iraqi Penal Law no. 111, of 1969 and its Amendments. Al Maktaba Al Qanuniya. Baghdad.

Iraqi Trademarks Law of 1957. Available online at www.appimaf.org

Kenny, D. (2009) 'Equivalence' In: Baker, M. \& Saldinha, M. (eds.) Routledge Encyclopedia of Translation Studies ( $2^{\text {nd }}$ edition) Routledge, New York.

Kurzon, D. (1984). 'Theme, Hyper Theme, and the Discourse Structure of British legal Texts'. Text 4, (1) 31-56

Lewis, M. (2002) The Lexical Approach: The State of ELT and a Way Forward. Thomson, Australia.

Lobner, S. (2002) Understanding Semantics. Arnold, London .

Manning, C.D. \& Schutze, H. (1999) Foundations of Statistical Natural Language Processing. MIT Press, Cambridge.

Mathesius, V. (1939) ' On Information- Bearing Structure of the Sentence’ In: Kuno, F.(ed.) (1975) Harvard Studies in Syntax and Semantics pp.467-480.

Quirk,R. Greenbaum, S. and Svartvik, J.(1985) A Comprehensive English Grammar. Longman, London.

Sarcevic, S. (1997). New Approach to legal Translation. Kluwer law International. The Hague.

Saudi Arabia Anti-Bribery Law (1994). Arab World Quarterly. 9, (3), 283-287.

Shuy, Roger W. (1993) Language Crimes: The Use and Abuse of Language Evidence in the Courtroom. Blackwell, Cambridge.

The Iraqi Constitution of 2005. Available at www.costituteproject.org

Tiersma, P. (1999) legal language. Chicago University Press, Chicago.

Tiersma, P. (2005) ' Some Myths about Legal Language' Legal Studies .26, 8-26

Tiersma, Peter. (2008). 'The Nature of Legal Language' In: Gibbons, J., and Turell, M. T. (eds.). Dimensions of Forensic Linguistics. John Benjamins Publishing Company, Amsterdam.

Van Dijk, A. (ed.) (1985). Hand book of Discourse Analysis. Vol.1. London: Academic Press. London. 